\title{
ANTENATAL CARE PRACTICES IN HILLY AREA OF EASTERN REGION OF NEPAL
}

\author{
RB Sah*, K Gaurav, DD Baral, N Jha and PK Pokharel \\ School of Public Health and Community Medicine, BP Koirala Institute of Health Sciences, Dharan, Nepal. \\ *Correspondence to : Dr Ram Bilakshan Sah, School of Public Health and Community Medicine, BP Koirala Institute of Health Sciences, Dharan, Nepal. \\ Email:bilaksah@yahoo.com
}

\begin{abstract}
Antenatal care is provided during pregnancy to save lives of mother and foetus. The World Health Organization recommends four focused visits as sufficient for normal pregnancy. The objective of this study was to find out the antenatal care practices and its impact on birth outcome. The cross-sectional study was conducted from 28th March to 10th April, 2013 among the residents of Dhankuta municipality where 246 households were taken as subjects. Convenient purposive sampling technique was applied. Semi-structured questionnaire was used and face to face interview was conducted. Chi-square test was applied to find out the significant difference between sociodemographic characteristics and outcome variable i.e. birth outcome \& antenatal care visits. Almost eighty eight percent of respondents attended ANC visits. The findings revealed that even though the fourth ANC visit was (82.4\%), almost $82.5 \%$ of the pregnant women took the tetanus toxoid (TT) injections, about $81.7 \%$ received iron tablets and nearly $57.7 \%$ received albendazole. Women with School Leaving Certificate and higher education level are more likely to ANC visits (95.4\%) than women with below SLC (87.9\%) and no education (66.7\%). Hindu women are more likely to have ANC visits $(91.2 \%)$ compared to women of other religion $(47.4 \%)(\mathrm{P}<0.001)$. Furthermore, economic variable shows stronger association with ANC visits $(\mathrm{P}<0.001)$. We conclude that the women of the surveyed communities have placed antenatal care as priority. Lack of money and education led some of the respondents not to attend the recommended antenatal care visits. Antenatal care checkup is important for favourable birth outcome.
\end{abstract}

Key Words: Pregnancy, Foetus, Antenatal Care \& Practices.

\section{INTRODUCTION}

Two of the most important indicators of health of a country are life expectancy and maternal mortality rates. ${ }^{1}$ It was supposed that interventions would be needed earlier during the pregnancy to identify women at risk of getting pregnancy related complications, if the mortalities were to be averted. ${ }^{2}$ The World Health Organization (WHO) recommends four focussed antenatal care (ANC) visits as sufficient for normal pregnancy. ${ }^{3}$ Antenatal Checkup includes education, counseling, screening and treatment to monitor ailments and to promote health of the mother and foetus.

Nepal Demography and Health Survey (NDHS) 2006 recommends that the quality of ANC can be assessed by looking at the type of provider, the number of visits and the timing of the first visit. ${ }^{4}$ The ANC visits by pregnant women is $43.7 \%$, institutional delivery is $17.7 \%$, delivery by Skilled Birth Attendants is $18.7 \%$ and postnatal checkups is $33 \%$ in Nepal. ${ }^{5}$ In South East Asian Region, ANC coverage in Sri Lanka is 99\% and $44 \%$ in Nepal, Skilled birth attendance during delivery in Sri Lanka is $99 \%$ and $19 \%$ in Nepal and Maternal Mortality Rate (MMR) is lowest in Sri Lanka (23/100,000 live birth) and highest in Nepal (539/100,000 live birth), all of which can be linked. ${ }^{6}$ Therefore, this study was conducted to find out the antenatal care practices and its impact on birth outcome among residents of Dhankuta Municipality.

\section{MATERIALS AND METHODS}

The cross-sectional study was conducted from $28^{\text {th }}$ March to $10^{\text {th }}$ April, 2013 among the residents of Dhankuta municipality in Eastern Nepal. Among 9 wards, the ward number 4 was randomly selected by lottery method. To represent the women for $62 \%$ antenatal care (ANC) visits (Alehagen SA et al in 2012) sample size calculated was 246. All the participants aged 15 to 49 years from the selected households were included in the study. Convenient purposive sampling technique was applied for data collection.

A written permission was taken from concerned authority and an informed verbal consent was taken from the participants of the study. Those families which were available after three visits and willing to give verbal consent were included in the study. Pretested semi-structured questionnaire was administered to the study subjects in the presence of investigator and face to face interview was conducted. 
The collected data was entered in MS Excel 2000. The analysis was done by using statistical software SPSS (Statistical Package for Social Science) 17.0 version. Chi-square test was applied to find out the significant difference between sociodemographic characteristics and outcome variable i.e. birth outcome \& antenatal care visits. The probability of occurrence by chance is significant if $\mathrm{P}<0.05$ with $95 \%$ Confidence Interval.

\section{RESULTS}

Table 1: Antenatal care practices $(n=246)$

\begin{tabular}{|c|c|c|}
\hline Characteristics & Frequency & Percent \\
\hline $\begin{array}{r}\text { ANC visit } \\
\text { Yes } \\
\text { No }\end{array}$ & $\begin{array}{c}216 \\
30\end{array}$ & $\begin{array}{l}87.8 \\
12.2\end{array}$ \\
\hline $\begin{array}{l}\text { If ANC visits done, then how } \\
\text { many visits } \\
\text { One } \\
\text { Two } \\
\text { Three } \\
\text { Four }\end{array}$ & $\begin{array}{c}12 \\
12 \\
14 \\
178\end{array}$ & $\begin{array}{c}5.6 \\
5.6 \\
6.5 \\
82.4\end{array}$ \\
\hline $\begin{array}{l}\text { Number of TT vaccine taken } \\
\text { No } \\
\text { One } \\
\text { Two }\end{array}$ & $\begin{array}{c}43 \\
18 \\
185\end{array}$ & $\begin{array}{c}17.5 \\
7.3 \\
75.2\end{array}$ \\
\hline $\begin{array}{l}\text { *Supplements taken during } \\
\text { pregnancy } \\
\text { Fe } \\
\text { Folic acid } \\
\text { Albendazole } \\
\text { None }\end{array}$ & $\begin{array}{c}201 \\
135 \\
142 \\
44\end{array}$ & $\begin{array}{l}81.7 \\
54.9 \\
57.7 \\
17.9\end{array}$ \\
\hline $\begin{array}{l}\text { *Consume during pregnancy } \\
\text { Alcohol } \\
\text { Cigaretttes } \\
\text { Tobacco } \\
\text { Others }\end{array}$ & $\begin{array}{c}16 \\
10 \\
12 \\
244\end{array}$ & $\begin{array}{c}6.5 \\
4.1 \\
4.9 \\
99.2\end{array}$ \\
\hline $\begin{array}{l}\text { **Place of delivery } \\
\text { Home } \\
\text { Health care facility }\end{array}$ & $\begin{array}{c}84 \\
142\end{array}$ & $\begin{array}{l}37.2 \\
62.9\end{array}$ \\
\hline $\begin{array}{l}\text { If home delivery, what instrument } \\
\text { used } \\
\text { Delivery kit (Sutkeri samagri) } \\
\text { Sterilized blade } \\
\text { Others (Knife, scissor) }\end{array}$ & $\begin{array}{l}14 \\
58 \\
12\end{array}$ & $\begin{array}{l}16.7 \\
69.0 \\
14.3\end{array}$ \\
\hline
\end{tabular}

*percentages are based on multiple responses

$* * n=226$ (As 16 respondents were pregnant \& 4 had abortion) ANC: Antenatal Care

Table 1 shows that eighty eight percent of respondents attended ANC visits. The findings revealed that the fourth ANC visit was usually satisfactory, other visits were more poorly attended. Almost eighty three percent of the pregnant women took the tetanus toxoid (TT) injections, about eighty two percent received iron tablets and nearly fifty eight percent received albendazole.

Table 2: Association between sociodemographic characteristics with antenatal services

\begin{tabular}{|c|c|c|c|c|}
\hline \multirow{2}{*}{ Characteriatics } & \multicolumn{2}{|c|}{ ANC visit } & \multirow{2}{*}{ Total } & \multirow{2}{*}{$\begin{array}{c}\mathbf{P} \\
\text { Value }\end{array}$} \\
\hline & Yes & No & & \\
\hline $\begin{array}{l}\text { Age group } \\
15-24 \\
25-34 \\
35-49\end{array}$ & $\begin{array}{l}56(84.8) \\
92(87.6) \\
68(90.7)\end{array}$ & $\begin{array}{c}10(15.2) \\
13(12.4) \\
7(9.3)\end{array}$ & $\begin{array}{c}66 \\
105 \\
75 \\
\end{array}$ & 0.292 \\
\hline $\begin{array}{l}\text { Religion } \\
\text { Hindu } \\
\text { Others (Buddhist, } \\
\text { Christian) }\end{array}$ & $\begin{array}{c}207(91.2) \\
9(47.4)\end{array}$ & $\begin{array}{c}20(8.8) \\
10(52.6)\end{array}$ & $\begin{array}{c}227 \\
19\end{array}$ & $<0.001$ \\
\hline $\begin{array}{l}\text { Ethnicity } \\
\text { Brahmin/Chhetri } \\
\text { Janajati/Kirati } \\
\text { Others(Dalit,Terai } \\
\text { caste) }\end{array}$ & $\begin{array}{c}87(90.6) \\
108(86.4) \\
21(84.0)\end{array}$ & $\begin{array}{c}9(9.4) \\
17(13.6) \\
4(16.0)\end{array}$ & $\begin{array}{c}96 \\
125 \\
25\end{array}$ & 0.266 \\
\hline $\begin{array}{l}\text { Education of } \\
\text { wife } \\
\text { Illiterate } \\
\text { Below SLC } \\
\text { SLC and above } \\
\end{array}$ & $\begin{array}{c}26(66.7) \\
87(87.9) \\
103(95.4) \\
\end{array}$ & $\begin{array}{c}13(33.3) \\
12(12.1) \\
5(4.6)\end{array}$ & $\begin{array}{c}39 \\
99 \\
108\end{array}$ & $<0.001$ \\
\hline $\begin{array}{l}\text { Education of } \\
\text { husband } \\
\text { Illiterate } \\
\text { Below SLC } \\
\text { SLC and above } \\
\end{array}$ & $\begin{array}{c}3(33.3) \\
95(93.1) \\
118(87.4) \\
\end{array}$ & $\begin{array}{c}6(66.7) \\
7(6.9) \\
17(12.6) \\
\end{array}$ & $\begin{array}{c}9 \\
102 \\
135 \\
\end{array}$ & 0.135 \\
\hline $\begin{array}{l}\text { Economic status } \\
\text { Below poverty } \\
\text { line }(<1.25 \text { US } \$) \\
\text { Above poverty } \\
\text { line }(\geq 1.25 \text { US } \$)\end{array}$ & $\begin{array}{l}80(79.2) \\
136(93.8) \\
\end{array}$ & $\begin{array}{l}21(20.8) \\
9(6.2) \\
\end{array}$ & $\begin{array}{l}101 \\
145 \\
\end{array}$ & $<0.001$ \\
\hline Total & 216 & 30 & & 246 \\
\hline
\end{tabular}

SLC: School Leaving Certificate.

Table 2 shows that women with Hindu religion are more likely to have ANC visits compared to women of other religions. The relationship between ANC visits and the highest education level of women shows that the utilization of ANC visits increases as education level increases. Furthermore, economic variable shows stronger association with ANC visits $(\mathrm{p}<0.001)$. 
Table 3: Association between birth outcome with antenatal services ( $n=246)$

\begin{tabular}{|l|c|c|c|c|}
\hline \multirow{2}{*}{ Characteristics } & \multicolumn{2}{|c|}{ ANC visit } & \multirow{2}{*}{ Total } & \multirow{2}{*}{ P-value } \\
\cline { 2 - 3 } & Yes & No & & \\
\hline & & & & \\
Outcome of 1st pregnancy & & & & \\
Live & $199(90.9)$ & $20(9.1)$ & 219 & \\
Others (Abortion, still birth) & $3(27.3)$ & $8(72.7)$ & 11 & \multirow{2}{*}{0.012} \\
Presently pregnant & $14(87.5)$ & $2(12.5)$ & 16 & \\
\hline & & & & \\
Fetal complications & & & & \\
Yes & $4(19.0)$ & $17(81.0)$ & 21 & \\
No & $195(98.5)$ & $3(1.5)$ & 198 & $<0.001$ \\
\hline & & & & \\
Birth weight of 1 ${ }^{\text {st baby }}$ & $7(30.4)$ & $16(69.6)$ & 23 & \\
$<2.5 \mathrm{~kg}$ & $173(98.9)$ & $2(1.1)$ & 175 & $<0.001$ \\
$2.5-3.5 \mathrm{~kg}$ & $19(90.5)$ & $2(9.5)$ & 21 & \\
$>3.5 \mathrm{~kg}$ & & & & \\
\hline
\end{tabular}

Fetal complications including birth asphyxia, jaundice, febrile illness and congenital malformations was also higher among them with no ANC.The proportion of low birth weight $(<2.5 \mathrm{~kg})$ babies was higher in women with no ANC.

\section{DISCUSSION}

Poor antenatal care is an important risk factor for adverse pregnancy outcomes among women. ${ }^{2}$ In current study, the ANC visits were made by $87.8 \%$ of women which was higher than study conducted by Sanjel S et al in Nepal (78.9\%) of women, ${ }^{7}$ Pradhan A in Nepal (78\%), ${ }^{8}$ National average (43.7\%). ${ }^{4}$ This shows that the women in Hilly area of Eastern region of Nepal was aware about pregnancies involve some risks to the foetus, and to prevent, detect and manage complications early before they become life-threatening emergency. Shiffman suggested that antenatal visits enable health personnel to provide information about nutrition, hygiene, and danger signs. ${ }^{9}$ Our study showed very less $(12.2 \%)$ of women did not attend antenatal services. It may be due to fear/ embarrassment, problems not felt, thought not necessary, did not have time and unclear response.

Almost eighty two percent of respondents completed four ANC visits which is higher than study conducted by Sanjel $\mathrm{S}$ et al in Nepal $(61.4 \%)^{7}$ and Pradhan A in Nepal $(62 \%) .{ }^{8}$ Rooney argued that, whether antenatal care can prevent maternal mortality and serious morbidity is a difficult question to answer, but antenatal care is more beneficial in preventing adverse pregnancy outcomes when it is sought early in the pregnancy and is continued through delivery. ${ }^{10}$

A study conducted in Nepal showed that $95 \%$ of women have taken the iron tablet. ${ }^{7}$ Our study showed majority of women $(81.7 \%)$ have taken the iron tablet which is lower than other study ie $18.3 \%$ of women did not take the iron tablet, the reasons behind it were fear of side effect, due to dislike, due to not knowing its importance and due to forgetting to take iron tablets.

Almost eighty three percent of the pregnant women took the tetanus toxoid (TT) injections which is lower than other study conducted in Nepal (98\%) of women took tetanus toxoid (TT) vaccine ${ }^{7}$ and higher than study conducted by Pradhan A in Nepal $(72 \%),{ }^{8}$ the national average $(63.0 \%) .{ }^{4,11}$

This study showed only sixty three percent of deliveries were carried out in hospital which is lower than a study conducted in Nepal $(66 \%)$ of deliveries were hospital deliveries. ${ }^{8}$

Age had a negative relationship with the utilization of ANC and it was found that the young women were more likely to seek antenatal care than older one. ${ }^{3,12}$ It is well recognized that women's current age play important role in the utilization of antenatal care services. ${ }^{13}$ But our study showed that the old women were more likely to seek antenatal care than younger one. Obermeyer and Potter illustrated that the age at marriage was not significant predictors of utilization of antenatal care. ${ }^{14}$

This study showed that attendance of ANC vists among the women with SLC and above was higher (95\%) than those below SLC (87.9\%) and illiterate (66.7\%). Several studies have found a strong association between education and utilization of antenatal services. ${ }^{15}$ The result from this study also supports the positive association between the education and utilization of ANC visits. It may be due to the women with higher education might have an enhanced knowledge of modern health care services.

This study showed $79.2 \%$ of the poorest women and about $94 \%$ of the richest women have attended at least one ANC visit. In Nepal $22 \%$ of the poorest women and $67 \%$ of the richest women have attended at least one ANC. ${ }^{16}$ Similar findings with respect to socio-economic status are reported in Kenya. ${ }^{17,18}$ Women living in the poorest condition use antenatal services much less frequently than do those in the richest. Most of the women in 
our study have stated financial problem as the most common factor for non attendance of ANC.

There was stronger significant relationship between antenatal care visit and low birth weight babies $(p<0.001)$. Pregnant women who received antenatal care had infants with birthweights significantly higher than those who did not receive antenatal care $(\mathrm{P}<0.001) .{ }^{19}$ It was evident that a better outcome of pregnancy could be achieved if mothers seek antenatal care. Better outcomes can be attributed to maternal counseling, complete immunization coverage, longer health monitoring and longer duration of nutrient supplements during pregnancy. ${ }^{20}$

\section{CONCLUSION}

The women of the surveyed communities have placed high importance on antenatal care. Among the surveyed women, a large percentage had completed all four recommended ANC visits. Use of necessary medicine such as iron tablets, albendazole tablets and TT injection were also completed. Lack of money and education were the major problem which led some of the respondents not to attend the recommended antenatal care visits. The result of birth outcome showed that complete ANC visit was favourable. Therefore, increased attention is needed to ensure poor and less educated, obtain better access to antenatal services. Programs to improve birth outcome should include promotion of maternal literacy, and early and regular antenatal checkup.

\section{ACKNOWLEDGEMENT}

We would like to thank MBBS students who helped us during the study period and participants of Dhankuta Municipality.

\section{REFERENCES}

1. Central Bureau of Statistics. Nepal Census report 2001: Demography. Kathmandu: Central Bureau of Statistics; WHO.

2. Antenatal care in Developing country: An analysis of trends, levels and differentials, 1990 2001. WHO 2003.

3. Niroula B. Use of Health Service in Hill Village in Central Nepal. Health Transition Review 1994; 4(2): 151-66.

4. Ministry of Health and Population (MOHP) [Nepal], New ERA, Kathmandu, Nepal and Macro International Inc., Calverton, Maryland, USA. Demographic and Health Survey, Nepal; 2007. pp 135-55.

5. Stoltzfus RJ, Dreyfuss ML, Chwaya HM, Albonico M. Hookworm control as a strategy to prevent iron deficiency. Nutr Rev 1997; 55: 223-32.

6. Care Concern. A Quarterly Publication to Support Hope Foundation for Women \& Children of Bangladesh 2004; $2: 3$.

7. Sanjel S, Ghimire RH, Pun K. Antenatal care practices in Tamang community of hilly area in central Nepal. Kathmandu Univ Med J 2011; 34 (2): 57-61.

8. Pradhan A. Situation of antenatal care and delivery practices. Kathmandu Univ Med J 2005; 3 (3):260-70.

9. Shiffman J. Can Poor Countries Surmount High Maternal Mortality? Studies in Family Planning 2000; 31(4): 274-89.

10. Rooney C. Antenatal Care and Maternal Health: How Effective Is It? Maternal Health and Safe Motherhood Program.
World Health Organization, Division of Family Health, 1992. 11. Devkota B. A study of knowledge Attitude and Practices of mother and Maternal and Child Health Care at Pandurung Village 1994. Unpublished Masters Thesis, Faculty of Education, T.U., Kirtipur, Nepal.

12. Rahman M, Khudu B, Kane T, Mozumder AK, Reza M. Determinants of Antenatal Care Seeking Behaviors in Bangladesh: Reproductive Health in Rural Bangladesh. ICDDR, B: Center for Health and Population Research 1997; 1: 86-104. 13. Fosu GB 1994. Childhood morbidity and health care utilization: Cross national comparison of user related factors from DHS data. Social Science and Medicine 38: 1209-1220.

14. Obermeyer CM, Potter JE. Maternal Health Care Utilization in Jordan: A Study of Patterns and Determinants. Studies in Family Planning 1991; 22 (3): 177-87.

15. Becker S, Peters DH, Gray RH, Gultiano C, Blake RE. The determinant of use of maternal child health services in Metro Cebu, the Philippines, Health transition review 1993; 3: 77-89. 16. Campbell OMR, Graham WJ.The lancet maternal survival series steering group. Strategies for reducing maternal mortality: getting on with what works. Lancet 2006; 368:1284-99.

17. Van EIJK, Bles HM, Odhiambo F, Ayisi JG, Blokland IE, Rosen $\mathrm{DH}$ et al. Use of antenatal services and delivery care among women in rural western Kenya: A Community based survey. Reproductive health 2006; 6:32.

18. Statistics CB, Health M, Institute KMR. Centres for Disease Control and Prevention. DHS: M Kenya Demographic and Health Survey Nairobi, Kenya: Central Bureau of statistics; 2003.

19. Tayie FAK, Lartey A. Antenatal care and pregnancy outcome in Ghana, the importance of women's education. AJFAND 2008; 8 (3):291-303.

20. WHO. Reproductive health. Retrieved in July 2005 from: http:// www.who. int/ reproductive-health/ publications/ MSM_96_8/MSM_96_8_chapter1.en.html. 2005. 